\title{
The Application of Multiple Feedback Method in Sports Badminton Teaching
}

\author{
Nie Shangwei, Liu Dan \\ School of Physical Education, Chengdu University of Traditional Chinese Medicine, Chengdu, 611137, \\ Sichuan,China
}

Keywords: Multiple feedback method, Sports badminton, Physical education, Application research.

\begin{abstract}
At present, the demand for high-quality sports talents is increasing. Chinese Olympic athletes only got two Olympic gold medals in badminton game in 2016 Rio Olympic Games, which is far below the number of gold medals achieved in 2012. The country urgently needs a badminton team of very high quality and ability. Over the years, teaching scholars have been working hard to improve badminton teaching model and try to find ways to effectively improve the efficiency of badminton teaching. Competition teaching method, layered training method, and new media training method have been proposed. Although we achieved certain results, the effect is not obvious. Multiple feedback method is therefore presented. This paper focuses on the application of multiple feedback method in the teaching of sports badminton and the construction of multiple feedback method is given. The application of multiple feedback method in teaching system, teaching relation construction and student achievement improvement and so on is analyzed. By contrast, feedback method has a high application prospect in improving teaching system, building a democratic and harmonious relationship for teachers and students and improving student achievements.
\end{abstract}

\section{Introduction}

With the rapid development of the economy, the community puts forward higher and higher demands on talents, and the state has also put a high degree of attention to education. The State Sports General Administration pointed out in "Sports Industry Thirteen Five Plan in China" that: higher education schools must make full use of their own advantages and science and education to exercise students' body, vigorously strengthen sports-related majors, construct key disciplines and increase the pace of training sports talents. At present, the state's attention on students' physical quality is getting higher and higher. Students are the future of the motherland. Physical education is a branch of education, which can affect the physical development of students and can cultivate the sports talents of the motherland. In recent years, education scholars have a lot of research and discussion on sports teaching mode and teaching methods. Badminton has always been a popular sports activity in people's lives, which can effectively exercise students' sports ability, cultivate students' physical quality, and support an important part of sports major. Olympic Games promote the enthusiasm of students to learn badminton. Badminton Olympic athletes' achievements in our country have been the pride of the people. Our badminton athletes gained five gold medals in 2012 London Olympic Games, but only two badminton gold medals in 2016 Rio Olympic Games. This shows that the country is in urgent need of excellent badminton talents to inherit the old team's professional skills in order to carry forward our badminton development [1].

Multivariate feedback method is derived from the theory of cybernetics. Cybernetics refers to information set processing, statistical processing, impact of the system output part, and then feedback the results to the system. After entering the twenty-first century, there were a considerable part of the educators who proposed to apply multiple feedback method to sports badminton teaching, and effectively combine information theory, control theory and system theory. It is a strongly comprehensive teaching method. Multiple feedback method is based on the establishment of a good teaching environment. Teachers guide students to learn badminton knowledge and the use of skills, and show simple operation, cultivate the feelings between teachers 
and students, and feedback students' learning state, mastery and badminton training performance.

This paper focuses on the application of multiple feedback method in sports badminton teaching, analyzes the concept of multiple feedback method, which can be used to help students master badminton movement and game skills in sports badminton teaching and improve students' enthusiasm for learning badminton. The method can arouse students' enthusiasm to learn badminton and strengthen the link between teachers and students so that students' badminton professional results can be greatly improved [2].

\section{Multiple feedback method}

The concept of multiple feedbacks is first proposed in cybernetics, which can be used to extract system information efficiently. Add the affects you want to apply to the extracted information and finally feedback to the system. Multiple feedback method is based on three theories: information theory, control theory and system theory. In the early 21st century, educators pointed out the application of multiple feedback method to badminton teaching. This idea was practiced in some colleges and universities and has achieved good results. Multiple feedback method map is shown in Figure 1 below:

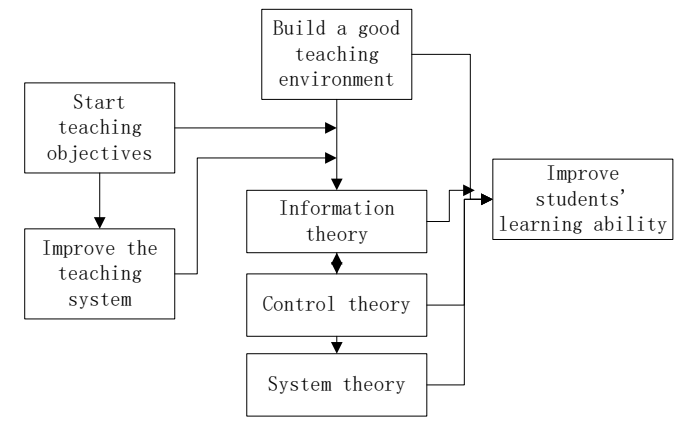

Figure 1 Multiple feedback method map

Figure 1 shows that multiple feedback method, with the use of information theory, control theory, and system theory, can provide a good teaching environment for teachers. Teaching environment is the guarantee of teaching quality. As we all know, teaching is composed of three factors: students, teacher and education process. Teachers play a leading role in teaching. Students are important recipients in teaching. Education process is a direct factor influencing teaching and has great floating. The impact of education not only includes course-ware, teaching materials, multimedia and other hardware equipment, but includes classroom atmosphere, the acceptance ability of students, teacher's own professional level, the relationship between teachers and students, school style and other factors. Teaching environment is an important factor affecting educational process. Teaching environment can directly affect the efficiency of a class or even a school, reflecting the total objective conditions. Bad teaching environment will greatly reduce the enthusiasm of students to learn and affect students learning ability cultivation adversely [3].

\section{Application of Multiple feedback Method in Sports Badminton Teaching}

Current badminton teaching model is too single and boring training greatly reduces training efficiency. Students will lose the fun of learning badminton after experienced several times' training. Although education scholars have been advocating education reform and proposing education innovation, there is no effective implementation. Badminton teaching is a part of China's sports industry and cannot be overlooked. This is related to national honor and national health and effective teaching methods and teaching methods must be sought to improve the quality of badminton teaching for our motherland to build a high-quality highly skilled badminton team, which has been the goal of sports workers and sports teachers. In order to implement this goal, a variety of teaching methods have been put forward, such as competition teaching method, stratified training method, and new media training method. These teaching methods are used and practiced in 
some badminton teaching, but the results are not optimistic. In view of this, multiple feedback method has been put forward and applied. By practice and comparison, it is understood that the application of multiple feedback method to badminton teaching has significantly better teaching achievement than other teaching methods. The method teaching effect comparison chart is shown in Figure 2 [4]:

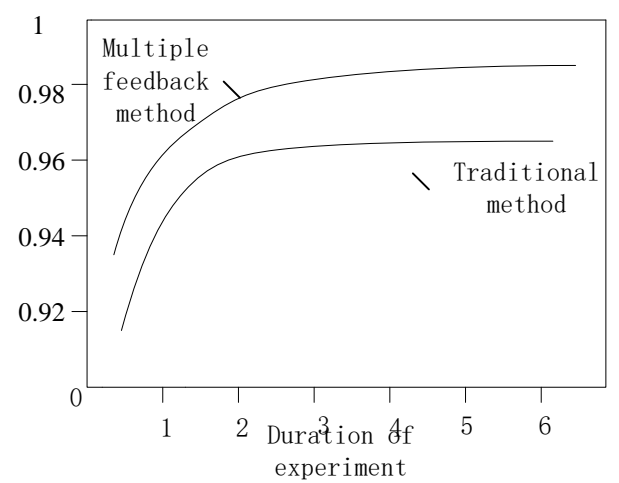

Figure 2 Comparison of teaching methods

Analysis of Figure 2 shows that the effect of multiple feedback method has been higher than traditional teaching methods. The method achieves the most prominent effect applied in a month, followed by a continuous upward trend, and the teaching effect is far greater than traditional teaching. The application of multiple feedback method in sports badminton is shown in Table 1 below [5]:

Table 1 Multiple feedback method in the application of sports badminton

\begin{tabular}{|l|l|}
\hline Application & Function \\
\hline Teaching system & Establish a sound teaching system \\
\hline $\begin{array}{l}\text { Constructing } \\
\text { teaching } \\
\text { relationships }\end{array}$ & $\begin{array}{l}\text { Build democracy and freedom between } \\
\text { teachers and students }\end{array}$ \\
\hline $\begin{array}{l}\text { Improve teaching } \\
\text { achievement }\end{array}$ & Improve students' achievement \\
\hline
\end{tabular}

Analysis of Table 1 shows that multiple feedback method can improve the teaching system of sports badminton. Research statistics show that it can improve the teaching system to promote students' positive emotions and teachers a good teaching state and promote emotional communication between teachers and students. If students and teachers are of antagonistic state, it will be very detrimental to the study of badminton students, so teachers have the responsibility and obligation to establish a perfect teaching system. The students in the classroom can be more serious and concentrated, and actively participate in training activities so as to greatly improve the efficiency of badminton learning.

Multiple feedback method can provide a kind of democratic and free relationship for students and teachers. This is different from the relationship between despotism and laissez-faire. Democracy emphasizes the relationship between teachers and students and students occupy the main position. The teacher plays the role of guidance and supervision. Democracy and free relationship can increase the self-esteem of students' learning, have a high degree of initiative in learning, rather than passive reception and achieve the goal of teaching through this way of learning.

Multiple feedback method can effectively improve the students' badminton learning results. The survey shows that students achievement rate with the use of multiple feedback method teaching is much higher than that of traditional method because multiple teaching method can effectively improve students' own psychological quality, physical balance, and is better able to adapt to high strength training and is of higher tactical literacy. 


\section{Conclusion}

Through the analysis of this article, we can understand that traditional teaching methods (competition teaching method, stratified training method, new media training method) have many drawbacks and cannot improve the teaching quality of sports badminton and meet the community demand for high-quality badminton talents. Multiple feedback method is based on information theory, control theory and system theory. Multivariate feedback method can improve teaching system effectively, construct a harmonious and harmonious relationship between teachers and students, improve students' achievement and has high application prospect.

\section{References}

[1] Wu Hongbang. Application of multiple feedback method in badminton teaching of physical education specialty [J]. Management Manager, 2014 (34): 437-437.

[2] Liu Xin. Application of multiple feedback teaching method in badminton teaching of sports training specialty ---- Taking badminton teaching of Xi'an Institute of Physical Education as an example [J]. Youth, 2015 (17).

[3] Xu Jin, Zhang Shan, Yao Wu. Study on the application of game method in badminton teaching of college physical education [J]. Contemporary Sports Science and Technology, 2012, 2 (26): 5-7.

[4] Guo Fenglan, Chen Lixin. Study on the application of competition teaching method in sports badminton teaching [J]. Fighting: Sports Forum, 2013, 5 (9): 48-50.

[5] Liu Xiaoli. The use of multiple intelligence theory in common college college badminton elective course teaching [J]. Inner Mongolia Sports Science and Technology, 2009 (1). 